\title{
A Review of the Desulfurization Processes Used for Waste Tire Pyrolysis Oil
}

\author{
Muhammad Nobi Hossain (D), Myung Kyu Choi and Hang Seok Choi *(D) \\ Department of Environmental Engineering, Yonsei University, Yonseidae-Gil 1, Wonju 26493, Korea; \\ mnhossain.8911@gmail.com (M.N.H.); cmg9411@yonsei.ac.kr (M.K.C.) \\ * Correspondence: hs.choi@yonsei.ac.kr; Tel.: +82-33-760-2485
}

check for updates

Citation: Hossain, M.N.; Choi, M.K.; Choi, H.S. A Review of the Desulfurization Processes Used for Waste Tire Pyrolysis Oil. Catalysts 2021, 11, 801. https://doi.org/ $10.3390 /$ catal11070801

Academic Editor: Angeliki

A. Lemonidou

Received: 6 May 2021

Accepted: 29 June 2021

Published: 30 June 2021

Publisher's Note: MDPI stays neutral with regard to jurisdictional claims in published maps and institutional affiliations.

Copyright: (c) 2021 by the authors. Licensee MDPI, Basel, Switzerland. This article is an open access article distributed under the terms and conditions of the Creative Commons Attribution (CC BY) license (https:// creativecommons.org/licenses/by/ $4.0 /)$.
Abstract: The increasing global population and the rapid industrial development associated therewith have increased the demand for fossil-derived fuel oils. The sources of fossil fuels are limited, and many studies have been being conducted to find alternative fuel sources. Waste tire pyrolysis oil (WTPO) attracts considerable attention as an alternative fuel because its properties are similar to those of diesel oil. However, WTPO has a high sulfur content of $>1.0 \mathrm{wt} \%$, which is above the environmental standard limit of $0.1 \mathrm{wt} \%$; therefore, it cannot be used in engines directly. It is thus highly necessary to remove sulfur compounds from tire-derived oils. However, finding an appropriate and environmentally friendly process is proving difficult. This review article presents the various desulfurization methods used to removal sulfur from WTPO, such as hydrodesulfurization (HDS), oxidative desulfurization (ODS), ultrasound-assisted oxidative desulfurization (UAOD), and acid treatment. Of these, HDS is the most expensive as it involves high consumption of hydrogen, high temperature $\left(\sim 450^{\circ} \mathrm{C}\right)$, and high pressure ( 200 bar), whereas UAOD is an efficient and economic method of reducing the sulfur content of WTPO.

Keywords: acid treatment; extraction; hydrodesulfurization; oxidative desulfurization; pyrolysis; waste tires

\section{Introduction}

Approximately 1.5 billion tons of waste tires are generated annually, and this amount is predicted to increase [1] in line with the increased demand for cars associated with economic development and the growth in population. For example, approximately six million tons of waste tires are produced annually in the USA and Europe [1-3].

Waste tires are disposed of at landfills or incinerated, but several methods have been designed to recycle tires for use in various applications or recover energy materials. However, these methods have certain limitations, and it is difficult to recycle tires because rubber monomers are crosslinked with sulfur during the vulcanization process to obtain mechanical strength and improve the thermostatic properties of rubber [4,5].

The tire material is a nonbiodegradable product; therefore, its disposal (landfilling and incineration) is problematic, unsustainable, and potentially causes both environmental and health-related problems. Large spaces are required for tire landfilling, and it favors the growth of insect- and mosquito-breeding grounds, which contribute to diseases. Incineration of waste tires produces harmful gases, such as $\mathrm{CO}, \mathrm{CO}_{2}, \mathrm{NOx}$, and $\mathrm{SOx}$, and the toxic polyaromatic hydrocarbon (PAH) fumes emitted pollute the environment and damage human health [5-7]. However, production of waste tire oil through a pyrolysis process attracts more attention than other polycyclic aromatic hydrocarbons (PAHs) because it has fuel properties similar to those of petroleum diesel. Waste tire pyrolysis oil (WTPO) has a higher heating value of 39.1-44 MJ $/ \mathrm{kg}$ compared to that obtained from other biomass such as palm $(18-20 \mathrm{MJ} / \mathrm{kg}$ ) or rice husk $(15 \mathrm{MJ} / \mathrm{kg})$. Furthermore, WTPO can be used as an alternate fuel for combustion engines, displacing fossil fuel consumption. Pyrolysis can play a crucial role in the clean conversion of waste tires. It is a thermochemical decomposition 
process that occurs at elevated temperatures and low pressures in the absence of oxygen which transforms tires into oil, solid char, and low-molecular liquids or gases [4,8-10].

It has been determined that WTPO has a higher sulfur content $(0.7-1.7)$ than the standard liquid fuel. This high sulfur content limits the application of WTPO in real combustion engines (Table 1) [5,11-13] because the presence of sulfur compounds (Figure 1) in WTPO causes the emission of highly toxic SOx, which is a considerable environmental and health threat, during its combustion. Thus, an efficient desulfurization method to remove sulfur compounds from WTPO prior to using it alone or in commercial diesel fuels is urgently needed.

Table 1. Ultimate analysis of WTPO.

\begin{tabular}{cccc}
\hline Ultimate Analysis & {$[5]$} & {$[12]$} & [13] \\
\hline Carbon & 85.67 & 85.6 & 85.5 \\
\hline Hydrogen & 10.04 & 10.1 & 8.9 \\
\hline Nitrogen & 1.15 & 0.4 & 0.6 \\
\hline Sulfur & 1.12 & 1.4 & 1.1 \\
\hline Oxygen & 2.02 & 2.5 & 4.7 \\
\hline
\end{tabular}

$$
\begin{gathered}
\mathrm{R}-\mathrm{SH} \\
\text { Thiols }
\end{gathered}-\mathrm{R}-\mathrm{S}-\mathrm{R}^{\mathrm{l}}
$$<smiles>Cc1cccs1</smiles>

2-methylthiophene

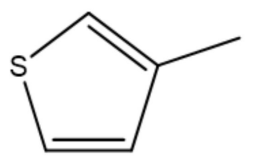

3-methylthiophene
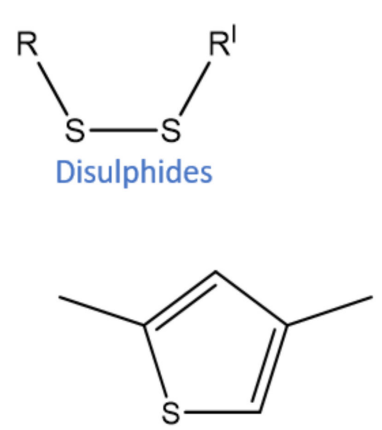

2,4-dimethylthiophene<smiles>c1ccsc1</smiles>

Thiophene<smiles>Cc1cc2ccccc2s1</smiles><smiles>c1ccc2sccc2c1</smiles>

Benzothiophene

\section{2-methylbenzothiophene}

Figure 1. Various sulfur compounds.

This article aims to review the various desulfurization methods used for WTPO and the associated possibility of using WTPO as an alternative energy source. The various current methods used in the desulfurization of fuel oil, mainly of diesel and model oil, are presented. It is expected that the oil refinery industry and researchers from other sectors who work on the desulfurization of fuel oil, especially of WTPO, will benefit from reading this review paper.

\section{Pyrolysis of Waste Tires}

Waste tires consist of high-polymer compounds, and many studies have researched the methods of processing waste tires in an environmentally friendly and efficient manner. Pyrolysis is considered to be the greenest and the most efficient process that allows the production of fuels and chemicals from waste tires, and in this respect, pyrolysis of waste tires is defined as thermochemical decomposition of organic compounds present in waste tires [14-17]. 
Waste tire pyrolysis occurs in an inert atmosphere at temperatures of $400-800{ }^{\circ} \mathrm{C}$. Partial gasification can also occur during pyrolysis in relation to the small amount of air present. Several pyrolysis methods have been developed in relation to various operating conditions, such as atmospheric, vacuum, catalytic fast, ultrafast (flash), and slow pyrolysis. Of these, catalytic fast pyrolysis has attracted the most research attention as the use of a catalyst in the pyrolysis process can improve the product yield, increase the reaction rate, and shorten the reaction time. Pyrolysis of waste tires has been studied in different types of reactors, such as fixed bed reactor screw kilns or rotary kiln reactors and fluidized bed reactors to obtain pyrolysis products [17-19].

\section{Characteristics of WTPO}

Pyrolysis of waste tires under thermal conversion yields three types of products: residual char, gases, and the main product, WTPO. The gases produced (syngas) comprise hydrocarbons, $\mathrm{H}_{2}, \mathrm{CO}, \mathrm{CO}_{2}$, and $\mathrm{H}_{2} \mathrm{~S}$, and they are mainly used in combustion to meet the heat energy required by the pyrolysis process. Solid black carbon is the main type of residual char obtained during waste tire pyrolysis, and it can be reutilized as carbon black or upgraded activated carbon, which is suitable for adsorbing heavy metals from water [20-22]. WTPO is a dark-brown dense liquid with a strong odor, and it is composed of hydrocarbons of various natures: aliphatic (alkanes), aromatic (benzene, toluene, xylene, ethylbenzene, and small amounts of PAH), and heteroatom compounds. The chemical value-added product (DL-limonene) is also found in WTPO, and it has an estimated market price of US\$ 2 per $\mathrm{kg}^{-1}$. All these chemicals can be separated and used as sources of energy in raw chemical materials and in the production of cosmetics, pharmaceuticals, and petrochemicals $[16,23,24]$. WTPO can also be directly used in generators, boilers, and combustion engines owing to its high heating value. However, as mentioned, WTPO contains relatively high amounts of sulfur and has high viscosity, which further requires catalytic upgrading if it is to be used as a fuel in vehicles $[25,26]$.

\section{The Various Desulfurization Methods Used to Upgrade WTPO}

Various chemical desulfurization methods, such as hydrodesulfurization (HDS), oxidative, extractive, adsorption, photocatalytic, and ultrasound-assisted oxidative desulfurization have been applied to upgrade WTPO, and acidic treatment has been applied as a physical desulfurization method. All these desulfurization methods are described below.

\subsection{Hydrodesulfurization of WTPO}

Hydrodesulfurization (HDS) is a common process typically used in the oil refinery industry; it is a process in which a hydrogen gas source is provided for the hydrotreatment of fuel oil to produce ultralow-sulfur fuel oil. The HDS process is a preferred method in the petroleum industry because of its high sulfur removal rate, catalyst stability, and its ease of adaptation to the feed. Catalysts play a crucial role in the HDS technology. It is possible to overcome the obstacles (sterically hindered sulfides) associated with the HDS process by improving the catalyst activity and providing appropriate process conditions $[27,28]$.

Jantaraksa et al. studied the HDS process to improve the quality of WTPO and focused on the reduction of sulfur compounds using three different catalysts, molybdenum (Mo), nickel-Mo (NiMo), or cobalt-Mo supported on alumina $\left(\gamma-\mathrm{Al}_{2} \mathrm{O}_{3}\right)$. The maximum sulfur removal efficiency $(87.8 \%)$ was obtained under the following optimum conditions: temperature $-250{ }^{\circ} \mathrm{C}$, time $-30 \mathrm{~min}$, catalyst loading $-\mathrm{NiMo} / \gamma-\mathrm{Al}_{2} \mathrm{O}_{3}, 2 \mathrm{wt} \%$, hydrogen pressure-2 bar [3].

Djandja et al. focused on the hydrotreatment of WTPO to produce a high-quality hydrocarbon-rich fuel oil, and a combination of tetralin and $\mathrm{H}_{2}$ was employed to provide a hydrogen source to enhance the hydrotreatment of WTPO. The study aimed to upgrade WTPO by reducing the sulfur (S) and nitrogen $(\mathrm{N})$ content and enable it to be used as a fossil fuel replacement. Several types of metal catalysts $(\mathrm{AC}, \mathrm{Ir} / \mathrm{C}, \mathrm{Pt} / \mathrm{C}, \mathrm{Ru} / \mathrm{C}$, and $\mathrm{Pd} / \mathrm{C})$ were used in that study. The lowest $\mathrm{N}(0.09 \mathrm{wt} \%)$ and $\mathrm{S}(15 \mathrm{ppm})$ content was 
achieved under the following reaction conditions: temperature $-430{ }^{\circ} \mathrm{C}$, time $-2 \mathrm{~h}$, catalyst dosage $-\mathrm{Pt} / \mathrm{C}, 15 \mathrm{wt} \%$, hydrogen pressure-6 MPa [29].

Till date, many HDS methods have been used to upgrade WTPO by reducing the amounts of undesirable nitrogen, sulfur, and unsaturated compounds in WTPO (Table 2). The studies conducted thus far show that the HDS process is a very effective method that can be used to improve the quality of WTPO, decrease the viscosity, and increase the saturated fraction content of WTPO [30-33]. However, it is very expensive because it involves high temperature and pressure conditions and high hydrogen consumption.

Table 2. Ultimate analysis of WTPO.

\begin{tabular}{|c|c|c|c|}
\hline Catalyst Used in the (HDS) System & Reaction Conditions & Sulfur Removal Efficiency & References \\
\hline $\mathrm{NiMo}, \mathrm{CoMo} / \gamma-\mathrm{Al}_{2} \mathrm{O}_{3}$ & $\begin{array}{c}\text { Temperature }-250{ }^{\circ} \mathrm{C} \text {, time }-30 \mathrm{~min} \text {, } \\
\text { catalyst dosage }-2 \mathrm{wt} \% \text {, hydrogen } \\
\text { pressure }-20 \mathrm{bar}\end{array}$ & $87.8 \%$ & [3] \\
\hline $\mathrm{AC}, \mathrm{Ir} / \mathrm{C}, \mathrm{Pt} / \mathrm{C}, \mathrm{Ru} / \mathrm{C}$, and $\mathrm{Pd} / \mathrm{C}$ & $\begin{array}{l}\text { Temperature }-400{ }^{\circ} \mathrm{C} \text {, time }-120 \mathrm{~min} \text {, } \\
\text { catalyst dosage }-15 \mathrm{wt} \%\end{array}$ & Reduced to $15 \mathrm{ppm}$ & [29] \\
\hline Copper-doped zeolite catalyst & $\begin{array}{c}\text { Temperature }-350^{\circ} \mathrm{C} \text {, time- }-90 \mathrm{~min}, \\
\text { catalyst dosage }-7.5 \mathrm{~g}\end{array}$ & $28.4 \%$ & [30] \\
\hline Ni-doped HZSM-5 zeolite & $\begin{array}{l}\text { Temperature }-350{ }^{\circ} \mathrm{C} \text {, catalyst } \\
\text { dosage }-7.5 \mathrm{~g} \text {, time-120 min }\end{array}$ & $29.2 \%$ & [31] \\
\hline $\mathrm{CoMo}-\mathrm{SiO}_{2}-\mathrm{Al}_{2} \mathrm{O}_{3}$ and $\mathrm{NiMo}-\mathrm{Al}_{2} \mathrm{O}_{3}$ & $\begin{array}{c}\text { Temperature-320-380 }{ }^{\circ} \mathrm{C} \text {, hydrogen } \\
\text { pressure-3-5 } \mathrm{MPa}\end{array}$ & $81.81 \%$ & [32] \\
\hline NiMo & $\begin{array}{c}\text { Temperature-275-375 }{ }^{\circ} \mathrm{C} \text {, hydrogen } \\
\text { pressure- } 65 \text { bar, hydrogen/oil } \\
\text { ratio-1000 vol } \%\end{array}$ & $92.0 \%$ & [33] \\
\hline
\end{tabular}

\subsection{Oxidative Desulfurization (ODS) of WTPO}

The process of oxidative desulfurization (ODS) (Figure 2) attracts research attention owing to the mild associated reaction conditions and the superdeep fuel oil desulfurization efficiency [33-35]. In the ODS process, organosulfur compounds are oxidized to sulfones and sulfoxides, and these are ultimately removed by polar extraction, adsorption, distillation, or decomposition [36,37]. Several oxidizing agents, such as $\mathrm{H}_{2} \mathrm{O}_{2}, \mathrm{O}_{2}, \mathrm{~K}_{2} \mathrm{FO}_{4}$, cumin hydroperoxide (CHP), and tert-butyl hydroperoxide (TBHP) have been used in the ODS process. Of these, most researchers have used $\mathrm{H}_{2} \mathrm{O}_{2}$ as an oxidizing agent because of its commercial availability and low cost; furthermore, it is nonpolluting and comparatively less corrosive [38-42].

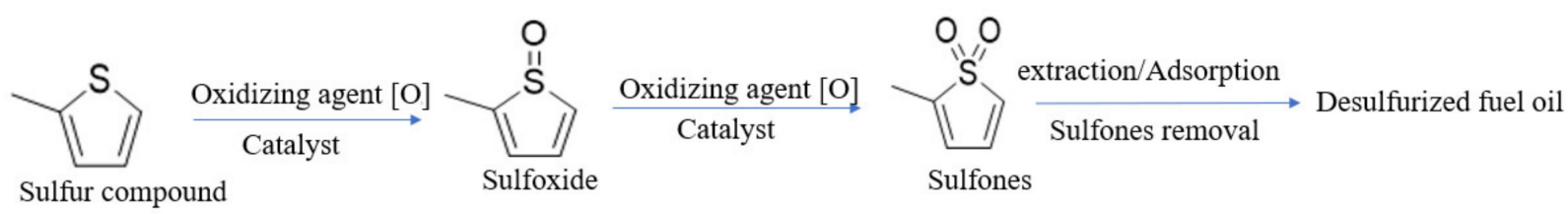

Figure 2. Mechanism involved in the oxidative desulfurization of fuel oil.

Zhang et al. studied the ODS of waste tire oil by combining oxidation and selective adsorption processes. The experiments using this ODS process were conducted in a batch reactor using a $\mathrm{H}_{2} \mathrm{O}_{2}$-formic acid mixture as the oxidant and $\mathrm{Al}_{2} \mathrm{O}_{3}$ as the sulfur adsorbent. The maximum ODS efficiencies of $81 \%$ and $84 \%$ were achieved from the waste tire crude oil and distillate, respectively, under the following conditions: temperature$80{ }^{\circ} \mathrm{C}$, time $-240 \mathrm{~min}$, oil $/ \mathrm{H}_{2} \mathrm{O}_{2}$ ratio- $1 / 4, v / v$, oxidant $\mathrm{H}_{2} \mathrm{O}_{2}$-formic acid ratio-1/1, $v / v$. The adsorbent $\mathrm{Al}_{2} \mathrm{O}_{3}$ also showed a high sulfur removal ability after three consecutive desulfurization-regeneration processes [2].

Aydin et al. studied desulfurization of waste tire oil using different types of catalysts $\left(\mathrm{CaO}, \mathrm{Ca}(\mathrm{OH})_{2}\right.$, and $\left.\mathrm{NaOH}\right)$, oxidants, and additives. In their work, formic acid- $\mathrm{H}_{2} \mathrm{O}_{2}$ and 
acetic acid- $\mathrm{H}_{2} \mathrm{O}_{2}$ mixtures were used as oxidants and $\mathrm{H}_{2} \mathrm{SO}_{4}$ was employed as an additive. The reduction of sulfur was more effective when the following were employed: $5 \mathrm{wt} \%$ $\mathrm{Ca}(\mathrm{OH})_{2}$ or $\mathrm{CaO}$ as the catalyst, a formic acid $-\mathrm{H}_{2} \mathrm{O}_{2}$ mixture and an acetic acid- $-\mathrm{H}_{2} \mathrm{O}_{2}$ mixture at a ratio of 1 to $2(v / v)$ as the oxidants, and $10 \% \mathrm{H}_{2} \mathrm{SO}_{4}$ as the additive. The maximum sulfur removal percentage achieved amounted to $83.75 \%$ [43].

Cherop et al. focused on modeling and optimizing oxidative desulfurization of WTPO using a central composite design method. In their study, a formic acid $-\mathrm{H}_{2} \mathrm{O}_{2}$ mixture was employed as the oxidizing agent, and after the oxidation reaction, oxidized sulfur compounds were removed by extraction with acetonitrile. The maximum sulfur removal of $86.05 \%$ was achieved at the reaction temperature of $54{ }^{\circ} \mathrm{C}$, oxidation time of $50 \mathrm{~min}, 8 \mathrm{~mL}$ $\mathrm{H}_{2} \mathrm{O}_{2}$ and $9 \mathrm{~mL}$ formic acid [44].

Trongkaew et al. studied photocatalytic oxidative desulfurization of WTPO followed by the use of a liquid-liquid extraction method and analyzed the effects of the photocatalyst, photoreaction temperature, oxidant, and extraction solvent on the degree of WTPO desulfurization. Titanium dioxide $\left(\mathrm{TiO}_{2}\right)$ was selected as the photocatalyst, air and $\mathrm{H}_{2} \mathrm{O}_{2}$ were used as oxidizing agents, and water, methanol, and acetonitrile were used as extracting solvents. The results showed that the oxidized sulfur compounds could be separated using a water-based biphasic system. The levels of the oxidized sulfur compounds were measured using a chromatographic analysis technique, and the maximum desulfurization degree of $43.6 \%$ was achieved under the following optimum conditions: photoreaction temperature of $50{ }^{\circ} \mathrm{C}$, photocatalyst dosage of $7 \mathrm{~g} / \mathrm{L}$, reaction time of $7 \mathrm{~h}$, and extraction solvent (acetonitrile)/pyrolysis oil ratio of $4 / 1(v / v)$ [4].

A few studies that improved the quality of waste tire oil by reducing the sulfur content have also been conducted; all the ODS processes used in those studies are presented in Table 3.

Table 3. The various ODS methods used to remove sulfur from WTPO.

\begin{tabular}{|c|c|c|c|}
\hline Oxidation Desulfurization System & Reaction Conditions & Sulfur Removal Efficiency & References \\
\hline $\mathrm{H}_{2} \mathrm{O}_{2}-\mathrm{HCOOH} / \mathrm{Al}_{2} \mathrm{O}_{3}$ & $\begin{array}{l}\text { Reaction temperature- } 50-80{ }^{\circ} \mathrm{C} \\
\mathrm{H}_{2} \mathrm{O}_{2} \text {-formic acid ratio- } 1: 1-1: 4, v / v, \\
\text { reaction time- } 240 \mathrm{~min}\end{array}$ & $81 \%$ & [2] \\
\hline $\mathrm{TiO}_{2}-\mathrm{H}_{2} \mathrm{O}_{2}$ & $\begin{array}{l}\text { Reaction temperature- } 50^{\circ} \mathrm{C} \\
\text { reaction time }-420 \mathrm{~min}, \text { catalyst } \\
\text { dosage }-7 \mathrm{~g} / \mathrm{L} \text { of oil }\end{array}$ & $43.6 \%$ & [4] \\
\hline $\mathrm{SZrO}_{2} / \mathrm{SBA}-15-\mathrm{H}_{2} \mathrm{O}_{2}$ & $\begin{array}{c}\text { Reaction temperature }-70{ }^{\circ} \mathrm{C} \text {, } \\
\text { reaction time }-60 \mathrm{~min} \text {, catalyst } \\
\text { dosage }-1 \mathrm{wt} \%\end{array}$ & $59.49 \%$ & [12] \\
\hline $\mathrm{CaO}, \mathrm{Ca}(\mathrm{OH})_{2}, \mathrm{NaOH} / \mathrm{H}_{2} \mathrm{O}_{2}$ & $\begin{array}{l}\text { Reaction temperature }-50^{\circ} \mathrm{C} \text {, catalyst } \\
\text { dosage }-5 \mathrm{wt} \% \text {, acetic acid } / \text { formic } \\
\text { acid- }-\mathrm{H}_{2} \mathrm{O}_{2} \text { ratio- }-1: 2, v / v\end{array}$ & $83.75 \%$ & [43] \\
\hline $\mathrm{HCOOH}-\mathrm{H}_{2} \mathrm{O}_{2}$ /acetonitrile & $\begin{array}{c}\text { Reaction temperature- } 54^{\circ} \mathrm{C}, \\
\text { reaction time- } 50 \mathrm{~min}, \\
\text { acetonitrile/oxidized oil ratio-1:1, } \\
v / v\end{array}$ & $86.05 \%$ & [44] \\
\hline $\mathrm{H}_{2} \mathrm{O}_{2}-\mathrm{HCOOH} / \mathrm{Al}_{2} \mathrm{O}_{3}$ & $\begin{array}{l}\text { Reaction temperature }-50-80^{\circ} \mathrm{C}, \\
\mathrm{H}_{2} \mathrm{O}_{2} \text {-formic acid ratio- }-1: 1-1: 4, v / v, \\
\text { reaction time- } 240 \mathrm{~min}\end{array}$ & $81 \%$ & [2] \\
\hline
\end{tabular}

\subsection{Ultrasound-Assisted Oxidative Desulfurization (UAOD) of WTPO}

Ultrasound-assisted oxidative desulfurization (UAOD) is a method used to create an oxidation reaction with sulfur compounds under mild reaction conditions. This innovative UAOD technology has been introduced to improve the desulfurization efficiency of conventional ODS processes [45,46]. UAOD is more effective at removing sulfur than conventional ODS processes due to its cavitation process. Cavitation is a phenomenon that is attributed to the formation, growth, and collision of microbubbles in the liquid medium, 
and it generates excessive heat energy and pressure in the reaction medium. The physical and chemical effects of the cavitation phenomena improve the oxidation reaction rate in the UAOD process by increasing the interfacial mass transfer rate between the hydrocarbon and oxidant phases [47-51].

Chen et al. investigated the efficiency of removing sulfur from WTPO via the UAOD process using a transitional metal catalyst (phosphotungstic acid, $\mathrm{H}_{3} \mathrm{PW}_{12} \mathrm{O}_{40}$ ), a solution of oxidant $\mathrm{H}_{2} \mathrm{O}_{2}$, and a biphasic agent tetraoctylammonium bromide. The reaction mixture was oxidized by ultrasound emission at the following conditions: oxidation time of $20 \mathrm{~min}$, oxidation temperature of $88^{\circ} \mathrm{C}$, and sonication frequency of $20 \mathrm{kHz}$; the oxidized WTPO was extracted with acetonitrile, followed by an adsorption process that employed $\mathrm{Al}_{2} \mathrm{O}_{3}$ as the adsorbent. The maximum desulfurization efficiency of $89 \%$ was obtained after the twostage UAOD process. The results indicated that the degree of desulfurization was affected by the catalyst amount, sonication time, and adsorption column diameter. It was also found that oxidation efficiency increased with an increase in the percentage of transitional metal catalysts. A longer sonication time also enhanced the oxidation process [52].

A cost-benefit analysis of removing organic sulfur from WTPO via a continuous flow process of UAOD was also conducted by Chen et al. The cost and percentage of sulfur removal were compared based on the use of one or two UAOD units. The cost for a single UAOD unit was measured as $\$ 0.70 /$ gal with a sulfur removal of $68 \%$, whereas the cost and removal percentage were $\$ 1.39 /$ gal and $90.91 \%$, respectively, for two UAOD units connected in a series. These results indicated that the continuous-flow UAOD process provides excellent economic benefits via the recycling of waste tires, along with elimination of environmental pollution, such as high $\mathrm{SO}_{2}$ and sulfate PM emission [53].

\subsection{Desulfurization of WTPO by Acid Treatment}

Islam et al. studied desulfurization of WTPO using an acid purification method that involved three stages: (1) removal of moisture, (2) desulfurization, and (3) distillation. Figure 3 represents an image of crude WTPO. In the first stage, crude WTPO was heated to $100{ }^{\circ} \mathrm{C}$ to remove moisture. In the second stage, concentric sulfuric acid ( $8 \%$ ) was mixed with moisture-free WTPO, followed by thorough stirring; this mixture was then allowed to settle for approximately $40 \mathrm{~h}$. The top layer of the mixture was a thin oil layer, the bottom layer was thick sludge, and the sulfur removal efficiency was $61.6 \%$. In the third stage, the top oil layer was used in the distillation process to separate the light and heavy hydrocarbons. The authors found that the distilled WTPO was similar to diesel fuel and $t$ could be used to replace diesel fuel in small engines. These results indicated that a blend of distilled WTPO (25\%) and diesel fuel (75\%) could be used without the need for engine modification [5].

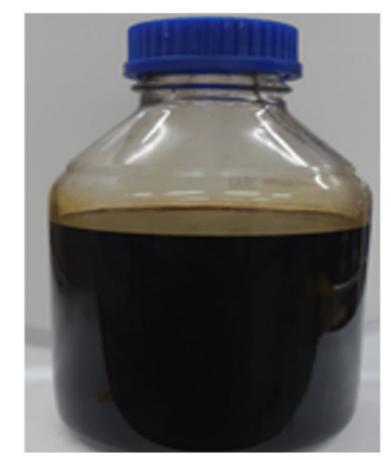

Figure 3. Crude waste tire pyrolysis oil (WTPO).

Rujiravorawut et al. investigated desulfurization of WTPO using three different conventional strong acids, $\mathrm{H}_{2} \mathrm{SO}_{4}, \mathrm{HNO}_{3}$, and $\mathrm{HCl}$, whereby the tire-derived oil and acid were mixed in a beaker at a ratio of 10:1. The sludge generated at the bottom of the beaker was removed, and the oil was neutralized with a sodium hydroxide base at a ratio of 10:1. 
The reaction was conducted at a temperature of $45^{\circ} \mathrm{C}$ with stirring at $800 \mathrm{rpm}$ for $2 \mathrm{~h}$ during the acid-base treatment, and the liquid oil product was then analyzed using gas chromatography (GC). The result showed a reduction in the quantity of WTPO following the acid treatment, owing to the generation of sludge. However, a major disadvantage of this method is that further treatment is required to dispose of the sludge [54].

Ahmad et al., Al-Lal et al., and Dog an et al. [55-58] used acid treatment for desulfurization of waste tire oil. However, the results showed that purification of waste tire oil using acid treatment lacks promise because toxic waste is generated when these strong acids are used in the purification process, and this exacerbates the associated environmental problems.

\section{Conclusions}

WTPO is an interesting hydrocarbon fuel feedstock source that has attracted considerable attention in the last few years. Tire-derived oil has a high potential to replace conventional liquid fuel owing to its high heating value and fuel properties, and its use would minimize the reliance on natural sources. Although the fuel properties of tirederived oil are similar to those of fossil fuels, the sulfur content limits its direct use in engines. During combustion in engines, the sulfur content in the fuel oil is converted to the toxic gas SOx, which contributes to the formation of acid rain and air pollution.

The HDS process is generally used in the oil refinery industry to remove sulfur compounds. However, the investment and operating costs of the HDS process are very high. To remove organosulfur and its derivatives, the HDS process is conducted under high temperature and pressure conditions and requires a large reactor volume. In addition, WTPO with a high sulfur content may not be suitable for use in the HDS process because of the increased hydrogen consumption and decreased catalyst efficiency. Another method of reducing the sulfur content of WTPO is the acid purification method, but the acid treatment process is not a promising method because a toxic waste residue of the sulfur content and sludge are generated during the process; this renders this method non-environmentally friendly.

Oxidative desulfurization (ODS) followed by adsorption/extraction attracts increasing attention as a desulfurization technique alternative to the HDS and acid treatment processes. ODS enables effective removal of sulfur compounds, and waste tire oil with ultralow sulfur content can be obtained under mild reaction conditions. This waste tire oil with low sulfur content can be used directly or blended in fuel engines. Interestingly, an innovative desulfurization technology known as UAOD combined with adsorption/extraction has been developed as an effective technology to remove sulfur and produce good-quality desulfurized waste tire oil under ambient conditions. In addition, the UAOD technology provides economic benefits to the waste tire management industry.

It is noteworthy that the presence of the catalyst improves the refractive index of WTPO and reduces the sulfur content. However, despite the advantages associated with catalytic desulfurization, some limitations still exist (such as oil recovery, the cost of the catalyst, and catalyst deactivation and regeneration). In addition, upgrading WTPO using different catalytic desulfurization methods in pilot and full-scale systems also poses a significant challenge. Therefore, a sustainable desulfurization method is urgently required to improve the economic aspects of the process.

Author Contributions: Conceptualization, M.N.H.; writing-original draft preparation, M.N.H.; writing-review and editing, M.N.H. and H.S.C.; visualization: M.K.C.; supervision: H.S.C. All authors have read and agreed to the published version of the manuscript.

Funding: This work was supported by a National Research Foundation of Korea (NRF) grant funded by the Ministry of Science, ICT, and Future Planning (MSIP) of Korea (NRF-2017R1A2B4009340), and by a grant from the Korea Institute of Energy Technology Evaluation and Planning (KETEP) and the Ministry of Trade, Industry \& Energy (MOTIE) of the Republic of Korea (No. 20184030202240). 
Acknowledgments: We thank the Ministry of Science, ICT, and Future Planning (MSIP) of Korea and the Korea Institute of Energy Technology Evaluation and Planning (KETEP) of the Republic of Korea for their financial support.

Conflicts of Interest: The authors have no conflicts of interest to declare.

\section{References}

1. Rowhani, A.; Rainey, T.J. Scrap Tyre Management Pathways and Their Use as a Fuel-A Review. Energies 2016, 9, 888. [CrossRef]

2. Zhang, Q.; Zhu, M.; Jones, I.; Zhang, Z.; Zhang, D. Desulfurization of Spent Tire Pyrolysis Oil and Its Distillate via Combined Catalytic Oxidation using $\mathrm{H}_{2} \mathrm{O}_{2}$ with Formic Acid and Selective Adsorption over $\mathrm{Al}_{2} \mathrm{O}_{3}$. Energy Fuels 2020, 34, 6209-6219. [CrossRef]

3. Jantaraksa, N.; Prasassarakich, P.; Reubroycharoen, P.; Hinchiranan, N. Cleaner alternative liquid fuels derived from the hydrodesulfurization of waste tire pyrolysis oil. Energy Convers. Manag. 2015, 95, 424-434. [CrossRef]

4. Trongkaew, P.; Utistham, T.; Reubroycharoen, P.; Hinchiranan, N. Photocatalytic Desulfurization of Waste Tire Pyrolysis Oil. Energies 2011, 4, 1880-1896. [CrossRef]

5. Islam, M.N.; Nahian, M.R. Improvement of Waste Tire Pyrolysis Oil and Performance Test with Diesel in CI Engine. J. Renew. Energy 2016. [CrossRef]

6. Dębek, C.; Walendziewski, J. Hydrorefining of oil from pyrolysis of whole tyres for passenger cars and vans. Fuel 2015, 159, 659-665. [CrossRef]

7. Williams, P.T. Pyrolysis of waste tyres: A review. Waste Manag. 2013, 33, 1714-1728. [CrossRef] [PubMed]

8. Choi, G.G.; Oh, S.J.; Kim, J.S. Scrap tire pyrolysis using a new type two-stage pyrolyzer: Effects of dolomite and olivine on producing a low-sulfur pyrolysis oil. Energy 2016, 114, 457-464. [CrossRef]

9. Ouyang, S.; Xiong, D.; Li, Y.; Zou, L.; Chen, J. Pyrolysis of scrap tyres pretreated by waste coal tar. Carbon Resour. Convers. 2018, 1, 218-227. [CrossRef]

10. Xu, S.; Lai, D.; Zeng, X.; Zhang, L.; Han, Z.; Cheng, J.; Wu, R.; Mašek, O.; Xu, G. Pyrolysis characteristics of waste tire particles in fixed-bed reactor with internals. Carbon Resour. Convers. 2018, 1, 228-237. [CrossRef]

11. Laresgoiti, M.F.; Caballero, B.M.; de Marco, I.; Torres, A.; Cabrero, M.A.; Chomón, M.J. Characterization of the liquid products obtained in tyre pyrolysis. J. Anal. Appl. Pyrolysis 2004, 71, 917-934. [CrossRef]

12. Hossain, M.N.; Choi, M.K.; Park, H.C.; Choi, H.S. Purifying of Waste Tire Pyrolysis Oil Using an SZrO2/SBA-15-H2O2 Catalytic Oxidation Method. Catalysts 2020, 10, 368. [CrossRef]

13. Zhang, G.; Chen, F.; Zhang, Y.; Zhao, L.; Chen, J.; Cao, L.; Gao, J.; Xu, C. Properties and utilization of waste tire pyrolysis oil: A mini review. Fuel Process. Technol. 2021, 211, 106582. [CrossRef]

14. Kordoghli, S.; Khiari, B.; Paraschiv, M.; Zagrouba, F.; Tazerout, M. Impact of different catalysis supported by oyster shells on the pyrolysis of tyre wastes in a single and a double fixed bed reactor. Waste Manag. 2017, 67, 288-297. [CrossRef]

15. Odejobi, O.J.; Sanda, O.; Abegunrin, I.O.; Oladunni, A.A.; Sonibare, J.A. Production of pyrolysis oil from used tyres and the effects of pyrolysis oil-gasoline blends on the performance of a gasoline-powered electric generator. Sci. Afr. 2020, 10, e00639. [CrossRef]

16. Lopez, G.; Alvarez, J.; Amutio, M.; Mkhize, N.M.; Danon, B.; Van der Gryp, P.; Görgens, J.F.; Bilbao, J.; Olazar, M. Waste truck-tyre processing by flash pyrolysis in a conical spouted bed reactor. Energy Convers. Manag. 2017, 142, 523-532. [CrossRef]

17. Antoniou, N.; Zabaniotou, A. Features of an efficient and environmentally attractive used tyres pyrolysis with energy and material recovery. Renew. Sustain. Energy Rev. 2013, 20, 539-558. [CrossRef]

18. Martínez, J.D.; Murillo, R.; García, T.; Veses, A. Demonstration of the waste tire pyrolysis process on pilot scale in a continuous auger reactor. J. Hazard. Mater. 2013, 261, 637-645. [CrossRef]

19. Miandad, R.; Rehan, M.; Barakat, M.A.; Aburiazaiza, A.S.; Khan, H.; Ismail, I.M.; Dhavamani, J.; Gardy, J.; Hassanpour, A.; Nizami, A.S. Catalytic Pyrolysis of Plastic Waste: Moving Toward Pyrolysis Based Biorefineries. Front. Energy Res. $2019,7$. [CrossRef]

20. Wang, F.; Gao, N.; Quan, C.; López, G. Investigation of hot char catalytic role in the pyrolysis of waste tires in a two-step process. J. Anal. Appl. Pyrolysis 2020, 146, 104770. [CrossRef]

21. Zhang, Y.; Williams, P.T. Williams. Carbon nanotubes and hydrogen production from the pyrolysis catalysis or catalytic-steam reforming of waste tyres. J. Anal. Appl. Pyrolysis 2016, 122, 490-501. [CrossRef]

22. $\mathrm{Xu}, \mathrm{J} . ; \mathrm{Yu}, \mathrm{J} . ; \mathrm{He}, \mathrm{W} . ;$ Huang, J.; Xu, J.; Li, G. Recovery of carbon black from waste tire in continuous commercial rotary kiln pyrolysis reactor. Sci. Total Environ. 2021, 722, 145507. [CrossRef]

23. Palos, R.; Kekäläinen, T.; Duodu, F.; Gutiérrez, A.; Arandes, J.M.; Jänis, J.; Castaño, P. Detailed nature of tire pyrolysis oil blended with light cycle oil and its hydroprocessed products using a NiW/HY catalyst. Waste Manag. 2021, 128, 36-44. [CrossRef]

24. Cheng, Z.; Li, M.; Li, J.; Lin, F.; Ma, W.; Yan, B.; Chen, G. Transformation of nitrogen, sulfur and chlorine during waste tire pyrolysis. J. Anal. Appl. Pyrolysis 2021, 153, 104987. [CrossRef]

25. Campuzano, F.; Jameel, A.G.; Zhang, W.; Emwas, A.H.; Agudelo, A.F.; Martínez, J.D.; Sarathy, S.M. On the distillation of waste tire pyrolysis oil: A structural characterization of the derived fractions. Fuel 2021, 290, 120041. [CrossRef]

26. Choi, G.G.; Oh, S.J.; Kim, J.S. Clean pyrolysis oil from a continuous two-stage pyrolysis of scrap tires using in-situ and ex-situ desulfurization. Energy 2017, 141, 2234-2241. [CrossRef] 
27. Weng, X.; Cao, L.; Zhang, G.; Chen, F.; Zhao, L.; Zhang, Y.; Gao, J.; Xu, C. Ultradeep Hydrodesulfurization of Diesel: Mechanisms, Catalyst Design Strategies, and Challenges. Ind. Eng. Chem. Res. 2020, 59, 21261-21274. [CrossRef]

28. Huang, T.; Xu, J.; Fan, Y. Effects of concentration and microstructure of active phases on the elective hydrodesulfurization performance of sulfided CoMo/ $\mathrm{Al}_{2} \mathrm{O}_{3}$ catalysts. Appl. Catal. B Environ. 2018, 220, 42-56. [CrossRef]

29. Djandja, O.S.; Wang, Z.; Duan, P.; Wang, F.; Xu, Y. Hydrotreatment of pyrolysis oil from waste tire in tetralin for production of high-quality hydrocarbon rich fuel. Fuel 2021, 285, 119185. [CrossRef]

30. Yuwapornpanit, R.; Jitkarnka, S. Cu-doped catalysts and their impacts on tire-derived oil and sulfur removal. J. Anal. Appl. Pyrolysis 2015, 111, 200-208. [CrossRef]

31. Namchot, W.; Jitkarnka, S. Upgrading of Waste Tyre-derived Oil from Waste Tyre Pyrolysis over Ni Catalyst Supported on Hzsm-5 Zeolite. Chem. Eng. Trans. 2015, 45, 775-780. [CrossRef]

32. Hita, I.; Gutiérrez, A.; Olazar, M.; Bilbao, J.; Arandes, J.M.; Castaño, P. Upgrading model compounds and Scrap Tires Pyrolysis Oil (STPO) on hydrotreating NiMo catalysts with tailored supports. Fuel 2015, 145, 158-169. [CrossRef]

33. Rezvani, M.A.; Shaterian, M.; Akbarzadeh, F.; Khandan, S. Deep oxidative desulfurization of gasoline induced by PMoCu@MgCu2O4-PVA composite as a high-performance heterogeneous nanocatalyst. Chem. Eng. J. 2018, 333, 537544. [CrossRef]

34. Kang, L.; Liu, H.; He, H.; Yang, C. Oxidative desulfurization of dibenzothiophene using molybdenum catalyst supported on Ti-pillared montmorillonite and separation of sulfones by filtration. Fuel 2018, 234, 1229-1237. [CrossRef]

35. Dizaji, A.K.; Mokhtarani, B.; Mortaheb, H.R. Deep and fast oxidative desulfurization of fuels using graphene oxide-based phosphotungstic acid catalysts. Fuel 2019, 236, 717-729. [CrossRef]

36. Rezvani, M.A.; Shaterian, M.; Aghbolagh, Z.S.; Akbarzadeh, F. Synthesis and Characterization of New Inorganic-Organic Hybrid Nanocomposite PMo11Cu@MgCu $\mathrm{O}_{4} @ \mathrm{CS}$ as an Efficient Heterogeneous Nanocatalyst for ODS of Real Fuel. ChemistrySelect 2019, 4, 6370-6376. [CrossRef]

37. Abbas, M.N.; Alalwan, H.A. Catalytic Oxidative and Adsorptive Desulfurization of Heavy Naphtha Fraction. Korean Chem. Eng. Res. 2019, 57, 283-288. [CrossRef]

38. Andevary, H.H.; Akbari, A.; Omidkhah, M. Highly efficient and selective oxidative desulfurization of diesel fuel using dual function [Omim] FeCl4 as catalyst/extractant. Fuel Process. Technol. 2019, 185, 8-17. [CrossRef]

39. Ribeiro, S.O.; Julião, D.; Cunha-Silva, L.; Domingues, V.F.; Valença, R.; Ribeiro, J.C.; de Castro, B.; Balula, S.S. Catalytic oxidative/extractive desulfurization of model and untreated diesel using hybrid-based zinc-substituted polyoxometalates. Fuel 2016, 168, 268-275. [CrossRef]

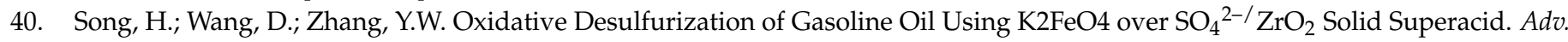
Mater. Res. 2011, 183-185, 2086-2090. [CrossRef]

41. Wang, D.; Qian, E.W.; Amano, H.; Okata, K.; Ishihara, A.; Kabe, T. Oxidative desulfurization of fuel oil Part, I. Oxidation of dibenzothiophenes using tert-butyl hydroperoxide. Appl. Catal. A Gen. 2003, 253, 91-99. [CrossRef]

42. Wang, Y.; Zhang, G.; Guan, T.; Xu, F.; Wu, J.; Zhou, E.; Wang, J.; Li, K. Ultra-Deep Oxidative Desulfurization of Model Oil Catalyzed by In Situ Carbon-Supported Vanadium Oxides Using Cumene Hydroperoxide as Oxidant. ChemistrySelect 2020, 5, 2148-2156. [CrossRef]

43. Aydın, H.; İlkılıç, C. Optimization of fuel production from waste vehicle tires by pyrolysis and resembling to diesel fuel by various desulfurization methods. Fuel 2012, 102, 605-612. [CrossRef]

44. Cherop, P.T.; Kiambi, S.L.; Musonge, P. Modelling and optimisation of oxidative desulphurisation of tyre-derived oil via central composite design approach. Green Process. Synth. 2019, 8, 451-463. [CrossRef]

45. Jalali, M.R.; Sobati, M.A. Intensification of oxidative desulfurization of gas oil by ultrasound irradiation: Optimization using Box-Behnken design (BBD). Appl. Therm. Eng. 2017, 111, 1158-1170. [CrossRef]

46. Choi, A.E.; Roces, S.; Dugos, N.; Futalan, C.M.; Lin, S.S.; Wan, M.W. Optimization of ultrasound-assisted oxidative desulfurization of model sulfur compounds using commercial ferrate (VI). J. Taiwan Inst. Chem. Eng. 2014, 45, 2935-2942. [CrossRef]

47. Choi, A.E.; Roces, S.; Dugos, N.; Wan, M.W. Oxidation by $\mathrm{H} 2 \mathrm{O} 2$ of bezothiophene and dibenzothiophene over different polyoxometalate catalysts in the frame of ultrasound and mixing assisted oxidative desulfurization. Fuel 2016, 180, 127-136. [CrossRef]

48. Dana, M.; Sobati, M.A.; Shahhosseini, S.; Ansari, A. Optimization of a continuous ultrasound assisted oxidative desulfurization (UAOD) process of diesel using response surface methodology (RSM) considering operating cost. Chin. J. Chem. Eng. 2020, 28, 1384-1396. [CrossRef]

49. Sinhmar, P.S.; Gogate, P.R. Ultrasound assisted oxidative desulfurization of simulated diesel using flow cell and longitudinal bath in combination with different oxidants. Chem. Eng. Process. Process Intensif. 2020, 153, 107968. [CrossRef]

50. Sinhmar, P.S.; Gogate, P.R. Ultrasound assisted oxidative desulfurization of simulated diesel using flow cell and longitudinal bath in combination with different oxidants. J. Ind. Eng. Chem. 2019, 80, 576-589. [CrossRef]

51. Lin, Y.; Feng, L.; Li, X.; Chen, Y.; Yin, G.; Zhou, W. Study on ultrasound-assisted oxidative desulfurization for crude oil. Ultrason. Sonochem. 2020, 63, 104946. [CrossRef]

52. Chen, T.C.; Shen, Y.H.; Lee, W.J.; Lin, C.C.; Wan, M.W. The study of ultrasound-assisted oxidative desulfurization process applied to the utilization of pyrolysis oil from waste tires. J. Clean. Prod. 2010, 18, 1850-1858. [CrossRef] 
53. Chen, T.C.; Shen, Y.H.; Lee, W.J.; Lin, C.C.; Wan, M.W. An economic analysis of the continuous ultrasound-assisted oxidative desulfurization process applied to oil recovered from waste tires. J. Clean. Prod. 2013, 39, 129-136. [CrossRef]

54. Rujiravorawut, N.; Missita, S.; Jitkarnka, S. Changes in Components of Tyre-derived Oil after Sulphur and Heteroatom Removal Using Three Acids. Chem. Eng. Trans. 2016, 52, 613-618. [CrossRef]

55. Ahmad, S.; Ahmad, M.I. Desulfurization of Oils; Produced from Pyrolysis of Scrap Tires. NUST J. Eng. Sci. 2013, 6, 27-32. [CrossRef]

56. Al-Lal, A.M.; Bolonio, D.; Llamas, A.; Lapuerta, M.; Canoira, L. Desulfurization of pyrolysis fuels obtained from waste: Lube oils, tires, and plastics. Fuel 2015, 150, 208-216. [CrossRef]

57. Doğan, O.; Çelik, M.B.; Özdalyan, B. The effect of tire derived fuel/diesel fuel blends utilization on diesel engine performance and emissions. Fuel 2012, 95, 340-346. [CrossRef]

58. Ahmad, S.; Ahmad, M.I.; Naeem, K.; Humayun, M.; Faheem, F. Oxidative desulfurization of tire pyrolysis oil. Chem. Ind. Chem. Eng. Q. 2016, 22, 249-254. [CrossRef] 